\title{
A Novel Pinkish-White Flower Color Variant Is Caused by a New Allele of Flower Color Gene W1 in Wild Soybean (Glycine soja)
}

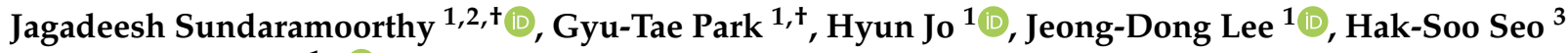 \\ and Jong-Tae Song $1, * \mathbb{B}$
}

Citation: Sundaramoorthy, J.; Park, G.-T.; Jo, H.; Lee, J.-D.; Seo, H.-S.; Song, J.-T. A Novel Pinkish-White Flower Color Variant Is Caused by a New Allele of Flower Color Gene W1 in Wild Soybean (Glycine soja). Agronomy 2021, 11, 1001. https:// doi.org/10.3390/agronomy11051001

Academic Editor: Hamid Khazaei

Received: 4 April 2021

Accepted: 14 May 2021

Published: 18 May 2021

Publisher's Note: MDPI stays neutral with regard to jurisdictional claims in published maps and institutional affiliations.

Copyright: (c) 2021 by the authors. Licensee MDPI, Basel, Switzerland. This article is an open access article distributed under the terms and conditions of the Creative Commons Attribution (CC BY) license (https:/ / creativecommons.org/licenses/by/ $4.0 /)$.
1 Department of Applied Biosciences, Kyungpook National University, Daegu 41566, Korea; jagadeesh@slu.se (J.S.); gyutae@knu.ac.kr (G.-T.P.); johyun@knu.ac.kr (H.J.); jdlee@knu.ac.kr (J.-D.L.)

2 Department of Plant Breeding, Swedish University of Agricultural Sciences, 23053 Alnarp, Sweden

3 Department of Agriculture, Forestry and Bioresources, Seoul National University, Seoul 08826, Korea; seohs@snu.ac.kr

* Correspondence: jtsong68@knu.ac.kr; Tel.: +82-539-507-753

$\dagger$ These authors contributed equally to this work.

\begin{abstract}
The enzyme flavonoid $3^{\prime}, 5^{\prime}$-hydroxylase $\left(\mathrm{F}^{\prime} 5^{\prime} \mathrm{H}\right)$ plays an important role in producing anthocyanin pigments in soybean. Loss of function of the $W 1$ locus encoding $\mathrm{F}^{\prime} 5^{\prime} \mathrm{H}$ always produces white flowers. However, few color variations have been reported in wild soybean. In the present study, we isolated a new color variant of wild soybean accession (IT261811) with pinkish-white flowers. We found that the flower's pinkish-white color is caused by $w 1-s 3$, a single recessive allele of W1. The SNP detected in the mutant caused amino acid substitution $\left(\mathrm{A}_{304} \mathrm{~S}\right)$ in a highly conserved SRS4 domain of $\mathrm{F}^{\prime} 5^{\prime} \mathrm{H}$ proteins. On the basis of the results of the protein variation effect analyzer (PROVEAN) tool, we suggest that this mutation may lead to hypofunctional $\mathrm{F}^{\prime} 5^{\prime} \mathrm{H}$ activity rather than non-functional activity, which thereby results in its pinkish-white color.
\end{abstract}

Keywords: flavonoid 3',5'-hydroxylase; Glycine soja; pinkish-white flower; soybean; W1 locus

\section{Introduction}

In plants, flavonoid $3^{\prime}, 5^{\prime}$-hydroxylase $\left(\mathrm{F}^{\prime} 5^{\prime} \mathrm{H}\right)$ is one of the key enzymes responsible for the blue and/or purple coloration in flower petals [1]. F3 ${ }^{\prime} 5^{\prime} \mathrm{H}$, together with dihydroflavonol 4-reductase (DFR), generally synthesize delphinidin-based anthocyanin pigments through the flavonoid biosynthesis pathway [2]. However, $\mathrm{F}^{\prime} 5^{\prime} \mathrm{H}$ enzymes are absent in several ornamental plants, such as rose (Rosa hybrid) and carnation (Dianthus caryophyllus). These ornamental plants only contain cyanidin and/or pelargonidin pigments, and therefore only have pink, yellow, and red as their natural colors but not purple or blue [3]. $\mathrm{F}^{\prime} 5^{\prime} \mathrm{H}$ is a cytochrome $\mathrm{P} 450$, which hydroxylates the naringenin or dihydrokaempferol biomolecules at the $3^{\prime}$ and $5^{\prime}$ positions of the $\beta$ ring to synthesize the delphinidin-based anthocyanin pigments [4,5]. The loss of function mutations in the $F 3^{\prime} 5^{\prime} H$ gene subsequently affects the production of delphinidin-based anthocyanin and results in flower color variations from blue to pink in several ornamental plants, for instance, petunia (Petunia hybrida) and gentian (Gentiana scabra) [6-8]. In leguminous crops, such as pea (Pisum satioum), lack of functional $\mathrm{F}^{\prime} 5^{\prime} \mathrm{H}$ enzyme results in rose-pink flower petals [3]. In contrast, soybean (G. max) showed that the variations in the $F 3^{\prime} 5^{\prime} H$ gene produced white flowers rather than color variations, such as pink flowers, which were observed in other plant species [3]. In addition, under W1 allelic background, the DFR-encoding genes, namely, W3 (DFR1) and W4 (DFR2), are epistatic to each other. Double mutations in these DFRs, i.e., w3 w4, cause near-white flowers in soybean [9].

In soybean, the $\mathrm{W} 1$ locus encoding $\mathrm{F}^{\prime} 5^{\prime} \mathrm{H}$ displays purple and white flower colors for its dominant and recessive alleles, respectively [10]. The white flower color observed in the 
common soybean cultivar, "Williams 82 ", is caused by the 65-bp insertion and 12-bp deletion in the $F 3^{\prime} 5^{\prime} H$ coding region, consequently resulting in premature translation [11,12]. We previously reported that $F 3^{\prime} 5^{\prime} H$ sequences from 99 landraces with white flowers were identical to that of "Williams 82" cultivar [13]. However, most of the wild soybean accessions (G. soja) have purple flowers and lack color variations among them, except for a few varieties that have been reported in the past two decades [14]. A white flower wild soybean accession, PI 424008C, was isolated from the progenies of the purple-flowered PI 424008A. Genetic analysis showed that the white color flower was caused by a mutation in the W1 locus [15].

In another study, we isolated two G. soja accessions (CW13381 and CW12700) with white flowers [16]. Genomic analysis of the W1 gene of CW13381 revealed the presence of an indel ( $\approx 90$-bp AT-repeat) in the second intron, whereas the CW12700 mutant had a unique single-nucleotide substitution that subsequently resulted in amino acid change $\left(\mathrm{N}_{300} \mathrm{~K}\right)$ in the substrate recognition site (SRS) 4 of $\mathrm{F}^{\prime} 5^{\prime} \mathrm{H}$ [16]. Another wild soybean accession (B00146) was found as a single plant with purple and white variegated flowers (B00146-m) [17]. From the progeny of B00146-m, the lines with white (B00146-w) and purple (B00146-r) flowers were developed. The $w 1-m$ allele of B00146-m showed the insertion of the Tgs1 transposon (CACTA family) in the first exon. Taken together, the loss of function of $\mathrm{F}^{\prime} 5^{\prime} \mathrm{H}$ in soybean always halts anthocyanin production, consequently resulting in white color flowers [16]. Apart from the aforementioned white color variants, a light-purplecolored G. soja variant (B09121) has been reported with a new w1-lp allele [18]. A unique single-base substitution in the nucleotide position 653 of $w 1$-lp mutant led to a noteworthy amino acid change $\left(\mathrm{V}_{210} \mathrm{M}\right)$. Flavonoid analysis showed that the $w 1$-lp mutant had a scarce number of major anthocyanins commonly detected in purple flowers. However, there was no difference in the transcription level between the alleles of $w 1-l p$ and W1. On the basis of their results, the authors suggested that an SNP mutation in the $F 3^{\prime} 5^{\prime} H$ gene may lead to reduced $\mathrm{F}^{\prime} 5^{\prime} \mathrm{H}$ enzymatic activity [18].

In this study, we isolated a new color variation of a wild soybean accession (IT261811) with pinkish-white flowers. The objective of the present study was to determine the genetic basis of the new wild soybean variant with pinkish-white flower color and its allelic component that influences anthocyanin biosynthesis.

\section{Materials and Methods}

\subsection{Plant Material}

A wild soybean accession (IT261811) with pinkish-white flowers was obtained from the National Agrobiodiversity Center, Korea. Another wild soybean accession (IT182932) with purple flowers was used as the wild-type accession in the present study (Figure 1). $\mathrm{F}_{2}$ individuals derived from the cross between IT261811 and IT182932 were used for the segregation analysis. $\mathrm{F}_{2}$ progenies with two parental lines were grown in the experimental fields of Kyungpook National University (Gunwi, $36^{\circ} 07^{\prime}$ N, $128^{\circ} 38^{\prime}$ E, Korea).

\subsection{RT-PCR and Sequence Analysis}

RT-PCR analysis was performed using the first-strand cDNA method to determine the transcript levels of $F 3^{\prime} 5^{\prime} H$ (W1) and DFR2 (W4). The soybean Actin 1 gene (GmActin; Glyma.19G000900.1) was used as a loading control [19]. The PCR reactions were performed using primer pairs for respective genes described in Sundaramoorthy et al. [16]. Exons and introns of W1 (Glyma.13G072100) and W4 (Glyma.17G252200) were amplified using the primer pairs previously described in Park et al. [20]. PCR products were sequenced (SolGent, Daejeon, Korea) using the same primer pairs used in the aforementioned amplification procedure.

\subsection{Multiple Alignment Analysis of W1 Proteins}

The $\mathrm{F}^{\prime} 5^{\prime} \mathrm{H}$ protein sequences from 14 different plant species were obtained from the National Center for Biotechnology Information Conserved Domains Database (NCBI- 
CDD, https: / / www.ncbi.nlm.nih.gov/Structure/cdd/cdd.shtml; accessed on 10 January 2021) and used to perform multiple sequence alignment using the ClustalW analysis tool (http:/ / www.genome.jp/tools-bin/clustalw; accessed on 10 January 2021).

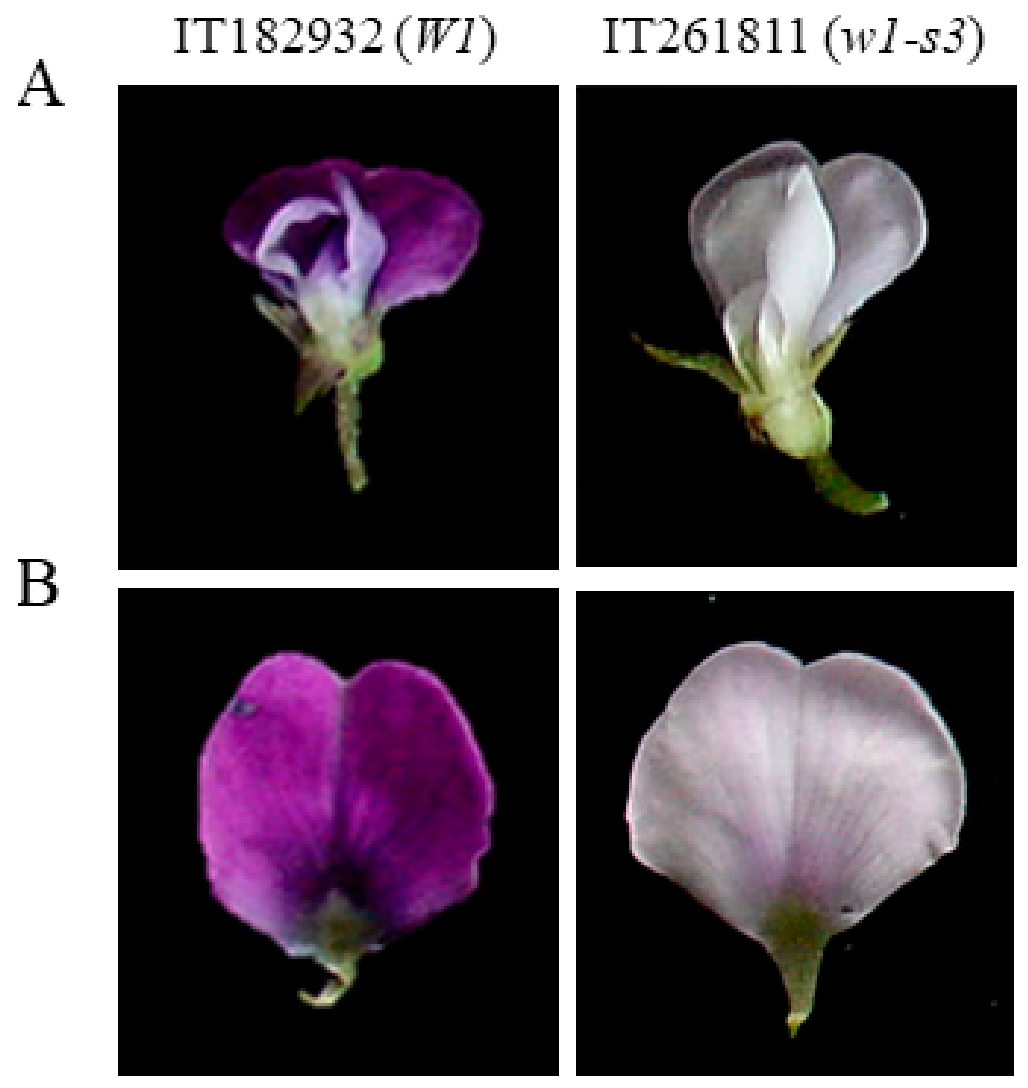

Figure 1. Photographic images showing the flower colors of the plant materials. Plant materials of wild soybean accessions IT182932 (purple flower) and IT261811 (pinkish-white). (A) A whole flower. (B) A banner petal.

\subsection{Prediction by Protein Variation Effect Analyzer (PROVEAN)}

To estimate the impact of non-synonymous SNPs causing amino acid sequence changes in the W1 proteins, we used the online server PROVEAN (http:/ / provean.jcvi. $\mathrm{org}$ /; accessed on 12 January 2021). Each amino acid substitution was given as input and the PROVEAN score was calculated [21,22].

\subsection{SNP-Based Genetic Analysis}

To study the phenomenon of segregation, cleaved amplified polymorphic sequence (CAPS) was developed to detect a single-base substitution in IT261811. PCR amplification was performed according to the procedure previously described by Park et al. [20]. Digestion of the PCR-amplified products were performed using DdeI (Enzynomics, Daejeon, Korea).

\section{Results and Discussion}

\subsection{Genetic Analysis of New Pinkish-White Flower Variant of Wild Soybean}

In the present study, we identified a pinkish-white flower variant (IT261811) among the wild soybean (G. soja) accessions (Figure 1). A total of $124 \mathrm{~F}_{2}$ individuals derived from the cross between IT261811 and IT182932 segregated into 95 plants with purple flowers and 29 plants with pinkish-white flowers (Table 1). The segregation fitted a 3:1 ratio, suggesting that a single recessive gene controls the pinkish-white mutant phenotype in IT261811. 
Table 1. Segregation and co-segregation analyses.

\begin{tabular}{|c|c|c|}
\hline \multicolumn{2}{|c|}{ Flower Color } & \multirow[t]{2}{*}{$W 1$} \\
\hline \multicolumn{2}{|c|}{ Segregation Ratios } & \\
\hline & $\mathrm{P} / \mathrm{PW} *$ & $\mathrm{~A} / \mathrm{H} / \mathrm{B}^{* *}$ \\
\hline Observed & 95:29 & $31: 64: 29$ \\
\hline Expected & $93: 31$ & $31: 62: 31$ \\
\hline Ratio & $3: 1$ & $1: 2: 1$ \\
\hline$x^{2}$ & 0.0056 & 0.0063 \\
\hline Probability $^{\dagger}$ & 0.94 & 0.99 \\
\hline
\end{tabular}

${ }^{*}$ P, purple; $\mathrm{PW}$, pinkish-white. ${ }^{* *} \mathrm{~A}$, wild homozygote; $\mathrm{H}$, heterozygote; $\mathrm{B}$, mutant homozygote; ${ }^{\dagger}$ not significant $(p<0.05)$.

\subsection{Molecular Analysis of the w1-s3 Variant}

In soybean (G. max), the W3 and W4 loci encoding DFR enzymes epistatically interact with each other in a W1 genotypic background [23]. However, in G. soja, the W3 locus is not involved in the determination of flower colors [24]. Taking this into consideration, we conducted RT-PCR for both $\mathrm{F}^{\prime} 5^{\prime} \mathrm{H}$ (W1) and (W4) genes to analyze alterations in gene expression. PCR products for $W 4$ were amplified with the size of 1175-bp. For W1 expression, $5^{\prime}(W 1-U)$ and $3^{\prime}(W 1-L)$ half regions of the $F 3^{\prime} 5^{\prime} H$ gene were amplified with the size of 331-bp and 558-bp, respectively (Figure 2A). Both W1 and W4 genes from IT261811 showed no significant difference in expression levels compared to that of wild-type IT182932, indicating that the mutant IT261811 had normal W1 and W4 expressions (Figure 2A). We analyzed the genomic sequences of $F 3^{\prime} 5^{\prime} H$ (W1) and DFR2 (W4) to determine the involvement of W1 and W4 in the allelic variation of the mutant, IT261811. First, we analyzed the genomic sequences of DFR2 (nucleotide positions -4 to +3416 ) from IT182932 and IT261811, and results showed no polymorphism between them. Next, the nucleotide sequences of $F^{\prime} 5^{\prime} H$ (nucleotide position -64 to +4534 ) from the mutant IT261811 showed a single-nucleotide substitution $(\mathrm{G}-\mathrm{T})$ in the third exon at nucleotide position +3763 (NCBI GenBank accession number: MW298105; Figure 2B), resulting in amino acid substitution $\left(\mathrm{A}_{304} \mathrm{~S}\right)$ relative to the corresponding sequences of the wild-type IT182932 (NCBI GenBank accession number: KX077984). The new mutant allele was designated as w1-s3.

Resequencing data of soybean accession in China, Korea, and the USA are publicly available through the NCBI [25-27]. With SNP and INDEL data on W1 locus from of 775 resequenced accessions on SoyKB (http:/ / soykb.org; accessed on 15 January 2021), we found no occurrence of SNP and/or INDEL on chromosome 13 at position 17,316,282 (Wm82.a2.v1), where $w 1$-s3 shows a single-nucleotide substitution. This prompted us to perform amino acid sequence alignment of $\mathrm{F}^{\prime} 5^{\prime} \mathrm{H}$ proteins from 14 different plant species from the NCBICDD database (Figure 2C) to determine the effects of single amino acid substitution in the $w 1$-s3 allele on the functionality of the $\mathrm{F}^{\prime} 5^{\prime} \mathrm{H}$ protein. The results showed that the amino acid change (Ser for Ala at position 304) in w1-s3 allele was located at the highly conserved position of SRS4 domain. SRS4 is the one of the six functional SRS domains in F3' $5^{\prime} \mathrm{H}$ enzymes, which plays an important role in substrate-binding specificity $[28,29]$.

In our previous study, a white-flowered EMS-induced mutant, PE1837 (w1-p1), showed a single amino acid substitution $\left(\mathrm{A}_{304} \mathrm{~T}\right)$ at a position similar to that of the mutant IT261811 (w1-s3) [16]. In the same study, we speculated that the hydroxyl group of $\mathrm{T}_{304}$ in $w 1-p 1$ may have inhibited the proper binding of the flavone substrate on the basis of the results of the 3 -D prediction tool, thereby leading to the loss of function of $\mathrm{F}^{\prime} 5^{\prime} \mathrm{H}$ protein [16]. Thus, the amino acid substitution $\left(\mathrm{A}_{304} \mathrm{~S}\right)$ identified in $w 1-s 3$ may also result in functional variation of $\mathrm{F}^{\prime} 5^{\prime} \mathrm{H}$ proteins. 
A

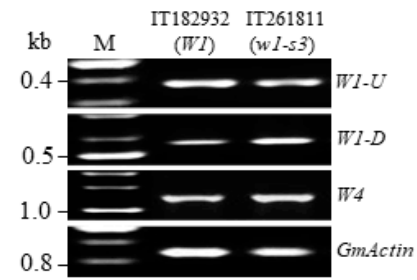

B

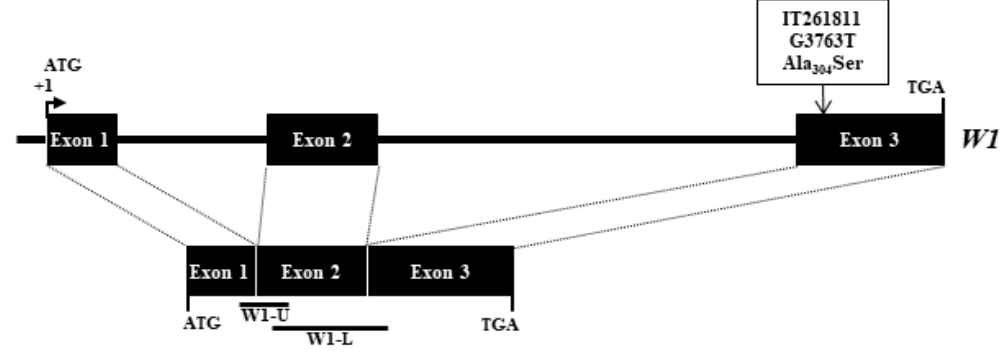

C

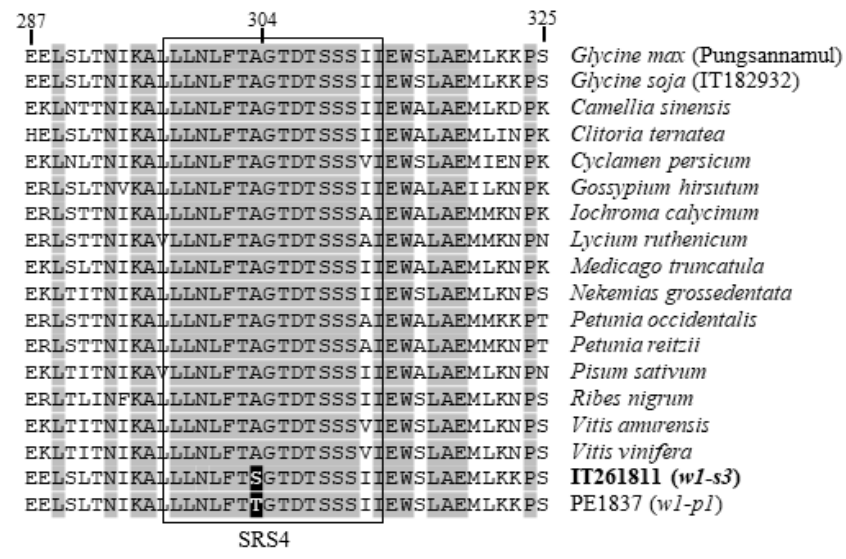

D

\begin{tabular}{|llll}
\hline Mutant & Variant & $\begin{array}{l}\text { PROVEAN } \\
\text { score }\end{array}$ & $\begin{array}{l}\text { Prediction } \\
\text { (cutoff=-2.5) }\end{array}$ \\
\hline IT261811 $(w 1-s 3)$ & $\mathbf{A}_{304} \mathbf{S}$ & -2.692 & Deleterious \\
PE1837 $(w 1-p l)$ & $\mathbf{A}_{304} \mathbf{T}$ & -3.550 & Deleterious \\
B09121 $(w 1-l p)$ Takahashi et $a l . ~(2010)$ & $\mathbf{V}_{210} \mathbf{M}$ & -2.673 & Deleterious
\end{tabular}

Figure 2. Expression profiles of $W 1$ and $W 4$ genes and schematic representation of the $F 3^{\prime} 5^{\prime} H$ allele along with $\mathrm{F}^{\prime} 5^{\prime} \mathrm{H}$ protein variation analysis. (A) Gene expression analysis of $W 1$ and $W 4$ through RT-PCR was performed in the purple-flowered line (IT182932) and the pinkish-white-flowered mutant line (IT261811). The $5^{\prime}$ and $3^{\prime}$ half regions of $F 3^{\prime} 5^{\prime} H$ are designated as $W 1-U$ and $W 1-L$, respectively. GmActin, a housekeeping gene, was used as the loading control. M, a 1-kb molecular marker. (B) Gene structure of $W 1$ and polymorphism between $W 1$ and $w 1$-s3 alleles. White boxes indicate mutational change in the recessive $w 1$-s3 allele at the $W 1$ locus. Black boxes indicate exons. W1-U and W1-L denote the $5^{\prime}$ and $3^{\prime}$ parts of W1, respectively. (C) Amino acid alignments of $\mathrm{F}^{\prime} 5^{\prime} \mathrm{H}$ proteins. The amino acid sequences of $14 \mathrm{~F}^{\prime} 5^{\prime} \mathrm{H}$ proteins from different plant species were compared with wild-type $\mathrm{F}^{\prime} 5^{\prime} \mathrm{H}$ and mutant proteins. Gray text indicates identical amino acids. White letters with a black highlight indicate relevant amino acid substitutions. Thick black box indicates the SRS4 domain. GenBank accession numbers of $\mathrm{F}^{\prime} 5^{\prime} \mathrm{H}$ proteins are as follows: Camellia sinensis, AAY23287; Clitoria ternatea, BAF49293; Cyclamen persicum, ACX37698; Gossypium hirsutum, ACH56524; Iochroma calycinum, AIY22750; Lycium ruthenicum, AGT57963; Medicago truncatula, XP_013459330; Nekemias grossedentata, AGO02173; Petunia occidentalis, BAF34571; Petunia reitzii, BAF34572; Pisum sativum, ADW66160; Ribes nigrum, AGI16385; Vitis amurensis, ACN38269; and Vitis vinifera, BAE47007. (D) PROVEAN scores of amino acid variations identified in $w 1-s 3, w 1-p 1$, and $w 1-l p$ mutants. The PROVEAN tool sets the threshold at -2.5 as default. 
Recently, prediction software tools have been widely used to identify the deleterious or neutral effect of SNPs in candidate genes on the basis of the biochemical severity of the amino acid substitution [30]. We used the Protein Variation Effect Analyzer (PROVEAN, http:/ / provean.jcvi.org/seq_submit.php; accessed on 12 January 2021) software tool that predicts whether an amino acid substitution has any impact on the functional activity of $\mathrm{F}^{\prime} 5^{\prime} \mathrm{H}$ (Figure 2D) [21]. The PROVEAN tool sets the threshold at -2.5 as default. If the score of the protein variant is $\leq-2.5$ as predicted, the variation has a "deleterious" effect. Scores above the threshold indicate that the variant has a "neutral" effect [21]. We used the mutants IT261811 (w1-s3) and PE1837 (w1-p1) for predicting the amino acid substitution's effect on $\mathrm{F}^{\prime} 5^{\prime} \mathrm{H}$ protein function, along with the previously reported lightpurple flower-bearing wild soybean mutant B09121 (w1-lp), whose $\mathrm{F}^{\prime} 5^{\prime} \mathrm{H}$ protein was described as hypofunctional due to an alteration in one of its amino acid residue [18]. The results showed that the $\mathrm{F}^{\prime} 5^{\prime} \mathrm{H}$ proteins of all the three $w 1-s 3$, w1-p1, and $w 1-l p$ mutants had deleterious effects, with $-2.692,-3.550$, and -2673 PROVEAN scores, respectively. However, the scores of $w 1-s 3$ and $w 1-l p$ were similar and at par with the cutoff score, suggesting that the $w 1-s 3$ mutant protein is similar to that of $w 1-l p$, which is more likely a hypofunctional $\mathrm{F}^{\prime} 5^{\prime} \mathrm{H}$ rather than a completely deleterious one.

\subsection{Co-Segregation of the W1 Polymorphism with Flower Color Phenotype}

We conducted the single-marker analysis, which is the simplest mapping analysis to detect the associations between a marker and phenotype (pinkish-white flower color). The CAPS marker designed from the SNP (G-T) generates a DdeI site (CTNAG) in the PCR-amplified product from the mutant parent, IT261811 (Figure 3A). The CAPS marker co-segregated with flower colors of the $\mathrm{F}_{2}$ individuals was derived from the cross between IT261811 and IT182932 (Figure 3B). The result of single-marker analysis showed that the W1 gene was highly associated with pinkish-white flower in this study $\left(n=124, p<0.0001, R^{2}\right.$ $=1$ ). Results also showed that genotype segregation fitted a 1:2:1 ratio (Table 1), indicating that the $w 1$-s 3 allele is recessive to W1. We concluded that the new $w 1$-s3 allele under the $w 1$ recessive allelic background produces pinkish-white flowers of the mutant IT261811 on the basis of the tight co-segregation between $w 1$-s3 and pinkish-white flowers.

$\mathbf{A}$

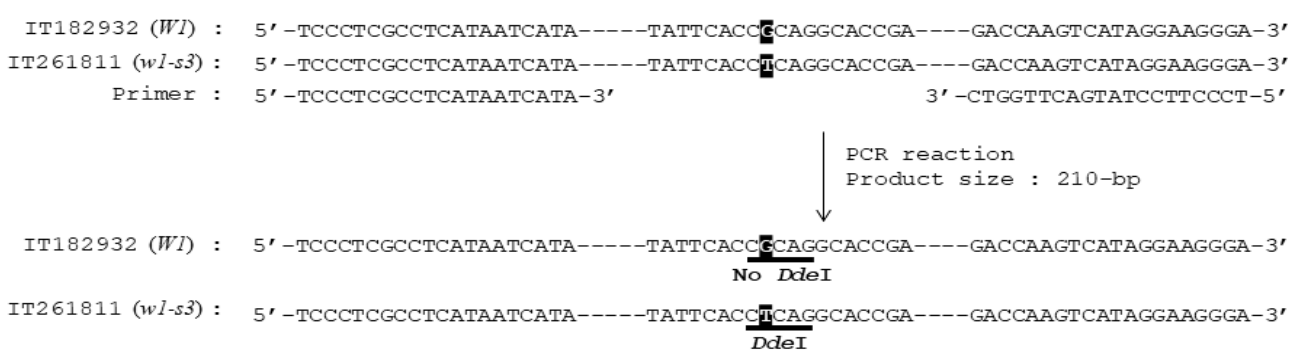

B

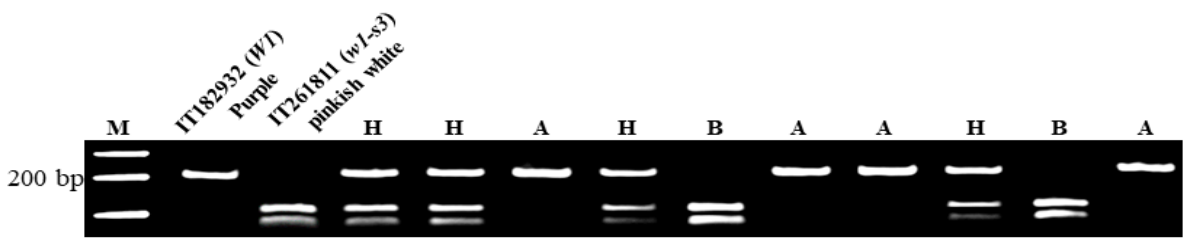

Figure 3. Schematic diagram of CAPS analysis and co-segregation of W1 polymorphism with the pinkish-white flower color phenotype. (A) CAPS analysis was aimed to detect an SNP in the w1-s3 allele (T, indicated in white font highlighted in black). The underlined DdeI site (CTNAG) was used for CAPS analysis. PCR products from IT261811 ( $w 1-s 3$ ) were $210 \mathrm{bp}$ in length and were digested with DdeI into 112- and 98-bp DNA fragments, whereas those from IT182932 (W1) remained uncut after digestion. (B) CAPS analysis shows the co-segregation of $W 1$ polymorphism and the flower color observed in the $\mathrm{F}_{2}$ population derived from the cross between IT261811 and IT182932. M, a 1-kb molecular marker; $H$, heterozygous $F_{2}$ plants with purple flowers; $A$, wild-type $\mathrm{F}_{2}$ plants with purple flowers; and $\mathrm{B}$, homozygous $\mathrm{F}_{2}$ plants with pinkish-white flowers. 
Author Contributions: Conceptualization, J.S. and J.-T.S.; data curation, J.S., G.-T.P., and H.J.; formal analysis, J.S. and G.-T.P.; investigation, J.S. and G.-T.P.; methodology, J.S., G.-T.P., and J.-T.S.; project administration, J.-T.S.; resources, J.-D.L. and J.-T.S.; supervision, J.-T.S.; writing—original draft, J.S., G.-T.P., H.J., and J.-T.S.; writing-review and editing, J.S., J.-D.L., H.-S.S., and J.-T.S. All authors have read and agreed to the published version of the manuscript.

Funding: This study was supported by the Kyungpook National University Research Fund, 2020.

Institutional Review Board Statement: Not applicable.

Informed Consent Statement: Not applicable.

Conflicts of Interest: The authors declare no conflict of interest.

\section{References}

1. Grotewold, E. The genetics and biochemistry of floral pigments. Annu. Rev. Plant Biol. 2006, 57, 761-780. [CrossRef] [PubMed]

2. Tanaka, Y.; Sasaki, N.; Ohmiya, A. Biosynthesis of plant pigments: Anthocyanins, betalains and carotenoids. Plant J. 2008, 54, 733-749. [CrossRef] [PubMed]

3. Moreau, C.; Ambrose, M.J.; Turner, L.; Hill, L.; Ellis, T.H.; Hofer, J.M. The B gene of pea encodes a defective flavonoid 3',5'hydroxylase, and confers pink flower color. Plant Physiol. 2012, 159, 759-768. [CrossRef] [PubMed]

4. Buzzell, R.; Buttery, B.; MacTavish, D. Biochemical genetics of black pigmentation of soybean seed. J. Hered. 1987, 78, 53-54. [CrossRef]

5. Tanner, G. Condensed tannins. In Plant Pigments and Their Manipulation; Davies, K.M., Ed.; Oxford: Blackwell, UK, 2004; Volume 14, pp. 154-184.

6. Matsubara, K.; Kodama, H.; Kokubun, H.; Watanabe, H.; Ando, T. Two novel transposable elements in a cytochrome P450 gene govern anthocyanin biosynthesis of commercial petunias. Gene 2005, 358, 121-126. [CrossRef] [PubMed]

7. Nakatsuka, T.; Nishihara, M.; Mishiba, K.; Hirano, H.; Yamamura, S. Two different transposable elements inserted in flavonoid 3',5'-hydroxylase gene contribute to pink flower coloration in Gentiana scabra. Mol. Genet. Genom. 2006, 275, 231-241. [CrossRef] [PubMed]

8. Snowden, K.C.; Napoli, C.A. Psl: A novel Spm-like transposable element from Petunia hybrida. Plant J. 1998, 14, 43-54. [CrossRef]

9. Park, G.T.; Sundaramoorthy, J.; Lee, J.-D.; Kim, J.H.; Seo, H.S.; Song, J.T. Elucidation of molecular identity of the W3 locus and its implication in determination of flower colors in soybean. PLoS ONE 2015, 10, e0142643. [CrossRef]

10. Palmer, R.G.; Pfeiffer, T.W.; Buss, G.R.; Kilen, T.C. Qualitative Genetics. In Soybeans: Improvement, Production, and Uses, 3rd ed.; Shibles, M., Harper, J.E., Wilson, R.F., Shoemaker, R.C., Eds.; Madison Inc.: Madison, WI, USA, 2004.

11. Takahashi, R.; Githiri, S.M.; Hatayama, K.; Dubouzet, E.G.; Shimada, N.; Aoki, T.; Ayabe, S.; Iwashina, T.; Toda, K.; Matsumura, H. A single-base deletion in soybean flavonol synthase gene is associated with magenta flower color. Plant Mol. Biol. 2007, 63, 125-135. [CrossRef] [PubMed]

12. Zabala, G.; Vodkin, L.O. A rearrangement resulting in small tandem repeats in the $F 3^{\prime} 5^{\prime} H$ gene of white flower genotypes is associated with the soybean W1 locus. Crop Sci. 2007, 47, S-113-S-124. [CrossRef]

13. Park, G.T.; Sundaramoorthy, J.; Park, J.B.; Lee, J.D.; Choi, K.S.; Kim, J.H.; Seo, H.S.; Park, S.-K.; Song, J.T. Diversity of the W1 gene encoding flavonoid 3', 5 '-hydroxylase in white- and purple-flowered soybeans. Plant Genet. Resour. 2015, 13, 213-218. [CrossRef]

14. Sundaramoorthy, J.; Park, G.T.; Lee, J.D.; Kim, J.H.; Seo, H.S.; Song, J.T. Genetic and molecular regulation of flower pigmentation in soybean. J. Korean Soc. Appl. Biol. Chem. 2015, 58, 555-562. [CrossRef]

15. Chen, Y.; Nelson, R.L. Identification and characterization of a white-flowered wild soybean plant. Crop Sci. 2004, 44, 339-342. [CrossRef]

16. Sundaramoorthy, J.; Park, G.T.; Chang, J.H.; Lee, J.D.; Kim, J.H.; Seo, H.S.; Chung, G.; Song, J.T. Identification and molecular analysis of four new alleles at the W1 locus associated with flower color in soybean. PLoS ONE 2016, 11, e0159865. [CrossRef] [PubMed]

17. Takahashi, R.; Morita, Y.; Nakayama, M.; Kanazawa, A.; Abe, J. An active CACTA-family transposable element is responsible for flower variegation in wild soybean Glycine soja. Plant Genome 2012, 5, 62-70. [CrossRef]

18. Takahashi, R.; Dubouzet, J.G.; Matsumura, H.; Yasuda, K.; Iwashina, T. A new allele of flower color gene W1 encoding flavonoid 3 ‘' 'hydroxylase is responsible for light purple flowers in wild soybean Glycine soja. BMC Plant Biol. 2010, 10, 155. [CrossRef] [PubMed]

19. Sandhu, D.; Atkinson, T.; Noll, A.; Johnson, C.; Espinosa, K.; Boelter, J.; Abel, S.; Dhatt, B.K.; Barta, T.; Singsaas, E.; et al. Soybean proteins GmTic110 and GmPsbP are crucial for chloroplast development and function. Plant Sci. 2016, 252, 76-87. [CrossRef]

20. Park, G.T.; Sundaramoorthy, J.; Lee, J.D.; Kim, J.H.; Park, S.K.; Seo, H.S.; Song, J.T. Association of new mutant allele, w4-nw, at W4 locus with near-white flower color in soybean. Crop Sci. 2016, 56, 1857-1864. [CrossRef]

21. Choi, Y.; Sims, G.E.; Murphy, S.; Miller, J.R.; Chan, A.P. Predicting the functional effect of amino acid substitutions and indels. PLoS ONE 2012, 7, e46688. [CrossRef]

22. Choi, Y.; Chan, A.P. PROVEAN web server: A tool to predict the functional effect of amino acid substitutions and indels. Bioinformatics 2015, 31, 2745-2747. [CrossRef] [PubMed] 
23. Hartwig, E.E.; Hinson, K. Inheritance of flower color of soybeans. Crop Sci. 1962, 2, 152-153. [CrossRef]

24. Park, G.T.; Sundaramoorthy, J.; Lee, S.; Lee, J.D.; Kim, J.H.; Park, S.K.; Seo, H.S.; Chung, G.; Song, J.T. Color variation in a novel Glycine soja mutant w4-s1 with pinkish-white flowers is controlled by a single recessive allele at the W4 locus. Crop Sci. 2017, 57, 3112-3121. [CrossRef]

25. Fang, C.; Ma, Y.; Wu, S.; Liu, Z.; Wang, Z.; Yang, R.; Hu, G.; Zhou, Z.; Yu, H.; Zhang, M.; et al. Genome-wide association studies dissect the genetic networks underlying agronomical traits in soybean. Genome Biol. 2017, 18, 1-14. [CrossRef] [PubMed]

26. Joshi, T.; Wang, J.; Zhang, H.; Chen, S.; Zeng, S.; Xu, B.; Xu, D. The evolution of soybean knowledge base (SoyKB). In Plant Genomics Databases; Dijk, A.V., Ed.; Humana Press: New York, NY, USA, 2017; pp. 149-159.

27. Valliyodan, B.; Qiu, D.; Patil, G.; Zeng, P.; Huang, J.; Dai, L.; Chen, C.; Li, Y.; Joshi, T.; Song, L.; et al. Landscape of genomic diversity and trait discovery in soybean. Sci. Rep. 2016, 6, 1-10. [CrossRef] [PubMed]

28. Ellis, S.W.; Hayhurst, G.P.; Smith, G.; Lightfoot, T.; Wong, M.M.; Simula, A.P.; Acland, M.J.; Sternberg, M.J.E.; Lennard, M.S.; Tucker, G.T.; et al. Evidence that aspartic acid 301 is a critical substrate-contact residue in the active site of cytochrome P450 2D6. J. Biol. Chem. 1995, 270, 29055-29058. [CrossRef]

29. Li, Q.; Fang, Y.; Li, X.; Zhang, H.; Liu, M.; Yang, H.; Kang, Z.; Li, Y.; Wang, Y. Mechanism of the plant cytochrome P450 for herbicide resistance: A modelling study. J. Enzym. Inhib. Med. Chem. 2013, 28, 1182-1191. [CrossRef] [PubMed]

30. Doss, C.G.P.; Nagasundaram, N.; Chakraborty, C.; Chen, L.; Zhu, H. Extrapolating the effect of deleterious nsSNPs in the binding adaptability of flavopiridol with CDK7 protein: A molecular dynamics approach. Hum. Genom. 2013, 7, 10. [CrossRef] [PubMed] 